\title{
Fluorescent and growth-regulating activity 2-phenylethenylphosphonic acid derivatives
}

\author{
C Yury N. Mitrasov,${ }^{1 *+}$ Nadezhda P. Savinova, ${ }^{1}$ Nadezhda A. Lukicheva, ${ }^{1}$ \\ Irina N. Smolina, ${ }^{1}$ Oksana V. Kondratyeva, ${ }^{2}$ V. Avenirovich Kozlov, ${ }^{3}$ \\ Tatiana V. Vasilieva, ${ }^{4}$ Svetlana M. Shchukina ${ }^{5}$ and Larisa M. Trofimova ${ }^{4}$ \\ ${ }^{1}$ Department of Bioecology and Chemistry. I.Ya. Yakovlev Chuvash State Pedagogical \\ University. K. Marks St., 38. Cheboksary, 428000. Chuvash Republic. Russia. \\ Phone:+7(8352)22-02-28.E-mail: mitrasovun@mail.ru. \\ ${ }^{2}$ Department of Professional Development of Teachers. Chuvash Republican Institute of \\ Education Ministry of Education of Chuvashia. M. Gorkogo Ave., 5. Cheboksary, 428001. \\ Chuvash Republic. Russia. Phone: +7 (8352) 58-45-22. E-mail: oxanalcr@yandex.ru \\ ${ }^{3}$ Department of Medical Biology with course of Microbiology and Virology; ${ }^{4}$ Department of Organic and \\ Pharmaceutical Chemistry. I.N. Ulyanov Chuvash State University. Moskovskiy Ave. 15. Cheboksary, 428015. \\ Chuvash Republic. Russia. Phone: ${ }^{3)}+7$ (8352) 45-26-97; 4) +7 (8352) 45-24-68 (внутренний номер 23-00). \\ E-mail: ${ }^{3)}$ pooh12@yandex.ru; ${ }^{4)}$ tava52@mail.ru
}

*Supervising author; ${ }^{+}$Corresponding author

Keywords: phosphorus pentachloride, styrene, carbamide, biuret, acetylurea, 2-phenylethenyl dichlorophosphonate, 2-phenylethenylphosphonic acid, fluorescence, germination, toxicity.

\section{Abstract}

The paper provides data on an improved method for the synthesis of 2-phenylethenylphosphonic acid dichloride by interacting of carbamide derivatives with 2-phenylethenyltrichlorophosphonium hexachlorophosphate, which is an intermediate adduct of the reaction of styrene and phosphorus pentachloride. Readily available urea, biuret, and acetylurea have been used as transformers of the adduct. It has been shown that carbamide derivatives are not only donors of the oxygen atom, but they also bind hydrogen chloride released at the stage of complexation into the corresponding hydrochlorides. This allows obtaining the target 2-phenylethenyldichlorophosphonate without admixture of the hydrochlorination by-product. The phenomenon of induced fluorescence of 2-phenylethenylphosphonic acid and its esters in the solid phase and in solution was revealed. The growth-regulating activity of 2-phenylethenylphosphonic acid and $O, O$-di(p-nitrophenyl)-2-phenylethenylphosphonate on the seed germination energy, laboratory and field germinations of grain and vegetable crops was established. It is shown that pre-sowing treatment of the Prokhorovka spring wheat seeds with a $0.0005 \%$ aqueous solution of $O, O$-di( $p$-nitrophenyl)-2-phenylethenylphosphonate leads to an increase in wheat yield by $21 \%$, which expands the range of products for this purpose. A study of the acute toxicity of 2-phenylethenylphosphonic acid according to LeBlanc on male rats kept on a standard vivarium diet showed that it has a two-phase effect. In the first phase, there are symptoms of damage to the motor part of the peripheral nervous system in the form of local seizures and the central nervous system in the form of the general suppression of motor activity and moderate relaxation of skeletal muscles, and in the second phase, the acid manifests itself in a general toxic effect. Determination of the $L D_{50}$ of 2-phenylethenylphosphonic acid showed that it belongs to the third class of toxicity low-hazard substances.

\section{References}

[1] D. Purdela, R. Valchanu. Chemistry of organic compounds of phosphorus. Moscow: Chemistry. 1972. 752p. (russian)

[2] E. Bergman, A. Bondi. Über die Reactionsweisen des Phosphorpentachlorides. I. Mitteil. Ber. 1930. Bd.63. No.5. P.1158-1173.

[3] G.K. Fedorova, A.V. Kirsanov. About the reaction of phosphorus pentachloride with unsaturated hydrocarbons. Journal of General Chemistry USSR. 1960. Vol.30. Iss.12. P.4044-4048. (russian)

[4] Yu.N. Mitrasov, N.P. Savinova. Reactions of phosphorus chlorides (IV and V) with derivatives of inorganic acids. Cheboksary: Chuvash State Pedagogical University. 2012. 107p. (russian) 
FLUORESCENT AND GROWTH-REGULATING ACTIVITY 2-PHENYLETHENYLPHOSPHONIC ACID DERIVATIVES 94-104

[5] K.N. Anisimov. Research in the field of derivatives of unsaturated phosphinic acids. Communication 4. Chlorides of arylvinylphosphinic acids. News of the USSR Academy of Sciences. O.Kh.N. 1954. No.5. P.803-805. (russian)

[6] Pat. 2471472 (USA), MПK C07F9/42. Phosphonic and thiophosphonic acid chlorides. W.H. Woodstock (USA). Chem. Abstrs. 1949. Vol.43. P.7499.

[7] A.S. 579279 (USSR), IPC C07F9/42. Method of obtaining dichloroanhydrides of $\beta$-alkoxyalkenylphosphonic acids / K. Dzhundubaev, A. Sulaimanov, B. Batyrkanova, T. Chyntemirova, T.N. Sadykov. Appl. 05.04.73; publ. 05.11.1977. Bul. No.41. (russian)

[8] B.V. Timokhin, V.N. Vengelnikova, A.V. Kalabina. Interaction of phosphorus pentachloride and its derivatives with sodium thiosulfate. Journal of General Chemistry USSR. 1981. Vol.51. Iss.12. P.28082809. (russian)

[9] Yu.N. Mitrasov, V.V. Kormachev. About the reaction of pyrosulfurous acid salts with chlorophosphonium compounds. Journal of General Chemistry USSR. 1985. Vol.55. Iss.4. P.938-939. (russian)

[10] Yu.N. Mitrasov, V.V. Kormachev, E.A. Anisimova. On the interaction of sodium dithionite with orgyltrichlorophosphonium hexachlorophosphorates. Journal of General Chemistry USSR. 1991. Vol.61. Iss.2. P.514-515. (russian)

[11] Yu.N. Mitrasov, N.P. Savinova, N.A. Chigarova, I.N. Smolina, O.V. Kondratieva, and M.A. Frolova. Reaction of $\alpha, \beta$-unsaturated organophosphorus compounds from chloride sulfuricum. Butlerov Communications. 2017. Vol.51. No.9. P.125-132. DOI: 10.37952/ROI-jbc-01/17-51-9-125

[12] V.V. Kormachev, Yu.N. Mitrasov, V.A. Kukhtin, T.M. Yakovleva, Yu.A. Kurskiy. New agents for the decomposition of adducts of phosphorus pentachloride with organic compounds. Journal of General Chemistry USSR. 1981. Vol.51. Iss.4. P.960-961. (russian)

[13] K.N. Anisimov, N.E. Kolobova, A.N. Nesmeyanov. Research in the field of unsaturated phosphinic acid derivatives. Communication 3. Chlorides of $\beta$-alkoxyethoxyvinylphosphinic and $\beta$ alkoxyethoxyvinyl-thiophosphinic acids. News Academy of Sciences of the USSR. O.Kh.N. 1954. No.5. P.799-802. (russian)

[14] L.N. Mashlyakovsky, B.I. Ionin. Unsaturated phosphinic acids and their derivatives. I. Synthesis of phosphinic acid chlorides with diene and acetylenic radicals. Journal of General Chemistry USSR. 1965. Vol.35. Iss.9. P.1577-1584. (russian)

[15] Yu.N. Mitrasov, V.V. Kormachev. About the interaction of adducts of phosphorus pentachloride with salts of carboxylic acids. Journal of General Chemistry USSR. 1983. Vol.53. Iss.7. P.1677-1678. (russian)

[16] Yu.N. Mitrasov, V.V. Kormachev. On the interaction of adducts of phosphorus pentachloride and o rganic compounds with carboxylic acid esters. Journal of General Chemistry USSR. 1985. Vol.55. Iss.5. P.1203-1204. (russian)

[17] Yu.N. Mitrasov, O.N. Mikhailova, N.S. Yaltseva, N.G. Nikifirov, V.V. Kormachev. About the interaction of amides of carboxylic acids and oximes with adducts of phosphorus pentachloride and alkenes. Journal of General Chemistry USSR. 1987. Vol.57. Iss.6. P.1417-1418. (russian)

[18] V.V. Rybkina, V.G. Rozinov, V.I. Glukhikh, A.V. Kolbina. The reasons for the formation of addition products during the phosphorylation of vinylalkyl ethers with phosphorus pentachloride. Journal of General Chemistry USSR. 1980. Vol.50. Iss.12. P.2663-2671. (russian)

[19] V.V. Rybkina, V.G. Rozinov, E.F. Grechkin The effect of aprotic solvents on the phosphorylating properties of phosphorus pentachloride. Journal of General Chemistry USSR. 1973. Vol.43. Iss.1. P.6266. (russian)

[20] Yu.N. Mitrasov, E.A. Anisimova, O.A. Kolyamshin, V.V. Kormachev. Reactions of $N$-oxides of pyridines with alkenyltrichlorophosphonium hexachlorophosphorates. Russian Journal of General Chemistry. 1998. Vol.68. Iss.1. P.164. (russian)

[21] Yu.N. Mitrasov, O.V. Kondratyeva, N.A. Lukicheva, I.V. Gordeeva, A.G. Kirillova. Reactions of amino acids with arylchlorophosphoranes and chlorophosphonium compounds. Russian Journal of General Chemistry. 2011. Vol.81. Iss.4. P.687-688. (russian)

[22] Pat. No. 2349596 Russian Federation, IPC C07F9/42. Method of obtaining styrylphosphonic acid dichloride. Yu.N. Mitrasov, I.N. Smolina, A.V. Dmitrieva, N.P. Savinova, O.V. Kondratyev. Appl. 12.20.2007; publ. 20.03.2009, Bul. No.8. (russian)

[23] J.R. Lakowicz. Principles of Fluorescence Spectroscopy. N.Y.: Springer Science. 2006. 960p.

[24] Yu.N. Mitrasov, V.A. Kozlov, T.V. Vasilyeva, O.V. Kondratyeva. Study of the fluorescent activity of 4-chlorophenylphosphonic acid. Chemistry and modernity: materials of the III All-Russia. Scientific conf. with int. participation. Cheboksary: Chuvash State Pedagogical University. 2015. P.50-52 (russian) 
[25] A.A. Avruiskaya, Yu.N. Mitrasov, V.A. Kozlov, N.A. Lukicheva, M.N. Otlashkina. Study of the fluorescent activity of 2-phenylethenylphosphonic acid. Problems of theoretical and experimental chemistry: abstracts. report XXV Ros. youth. scientific. conf., dedicated. 95th anniversary of the foundation of the Ural. University, Yekaterinburg, 22-24 Apr. 2015. Yekaterinburg: Ural Publishing House University. 2015. P.135-136. (russian)

[26] N.N. Melnikov. Pesticides. Chemistry, technology, application. Moscow: Chemistry. 1987. 712p. (russian)

[27] Patent No. 2595724 Russian Federation. IPC A01N57/14, A01P21/00. Stimulator for pre-sowing treatment of vegetable seeds. Yu.N. Mitrasov, A.A. Avruiskaya, I.N. Smolina, N.P. Savinova, O.V. Kondratyeva, M.A. Ershov. Appl. 03.27.2015; publ. 27.08.2016, Bul. No.24. (russian)

[28] Patent No. 2422451 Russian Federation. IPC C07F9/40, A01N 57/22, A01P 21/00. Spring wheat growth stimulator. O.V. Kondratyeva, T.V. Vasilieva, S.M. Shchukina, L.V. Eliseeva. Appl. 09.28.2009; publ. 06.27.2011, Bul. No.18. (russian)

[29] V.A. Kozlov, K.V. Illarionova, S.E. Gruzdev, Yu.N. Mitrasov, A.A. Avruiskaya, N.A. Lukicheva. Acute toxicity of 2-phenylethenylphosphonic acid. Materials of the Ninth International Scientific School "Science and Innovation-2014" ISS "SI-2014". Yoshkar-Ola: Volga State Technological University. 2014. P.185-186. (russian) 